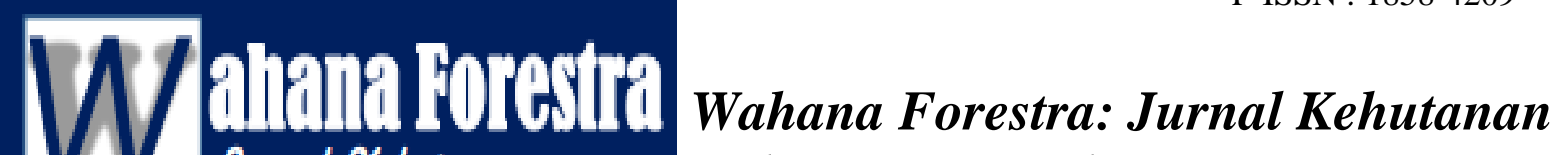 gutenal Kehutanan

\section{ANALISIS KELAYAKAN POTENSI EKOWISATA DI KAWASAN PENYANGGA TAHURA SULTAN SYARIF HASYIM KELURAHAN MINAS JAYA}

\section{(Feasibility Analysis Of Tourist Eco Potentials In The Sultan Syarif Hasyim Buffer Area Of Minas Jaya Region)}

\author{
Yan Nainggolan ${ }^{1}$, Eni Suhesti ${ }^{2}$, Ambar Tri Ratnaningsih ${ }^{2}$ \\ ${ }^{1}$ Fakultas Kehutanan Universitas Lancang Kuning \\ ${ }^{2}$ Staf Pengajar Fakultas Kehutanan Universitas Lancang Kuning \\ Jln. Yos Sudarso KM.08 Rumbai, Pekanbaru
}

E-mail : nainggolanmdn@gmail.com,suhestieni@unilak.ac.id,ambar@unilak.ac.id

Diterima: 18 Desember 2019, Direvisi: 09 Desember 2019, Disetujui: 31 Desember 2019

DOI: https://doi.org/10.31849/forestra

\begin{abstract}
This study aims to determine the potential for ecotourism and the feasibility of the potential of ecotourism in the Tahura buffer zone of Sultan Syarif Hasyim, Minas Jaya Village. This research was conducted by means of a survey to obtain data through interviews and questionnaires in which the sample of respondents was taken by accidental sampling. From the results of research that has been done, this area deserves to be developed into a tourist area because it is found the potential of ecotourism objects in the form of a wealth of natural resources such as flora and fauna, the beauty of the lake and its landscape, as well as many natural tourism activities that can be carried out. The Tahura Buffer Area of Sultan Syarif Hasyim, Minas Jaya Village, is feasible to be developed with the level of eligibility of each class with a score of each class, namely 846 attractiveness, 144 accommodations, 300 infrastructure. While for accessibility class it cannot be said to be feasible with a score of 455 .
\end{abstract}

Keywords: Tahura, Buffer Area, Potential, Feasibility

\begin{abstract}
ABSTRAK
Penelitian ini bertujuan untuk mengetahui potensi ekowisata dan nilai kelayakan potensi ekowisata di Kawasan Penyangga Tahura Sultan Syarif Hasyim Kelurahan Minas Jaya.Penelitian ini dilakukan dengan cara survey untuk memperoleh data-data melalui wawancara dan kuisioner dimana sampel responden diambil secaraaksidental sampling. Dari hasil penelitian yang telah dilakukan, kawasan ini layak untuk dikembangkan menjadi kawasan wisata karena ditemukan potensi objek ekowisata berupakekayaan sumber daya alam seperti flora dan fauna, keindahan danau dan bentang alamnya, serta banyak kegiatan - kegiatan wisata alam yang dapat dilakukan. Kawasan Penyangga Tahura Sultan Syarif Hasyim Kelurahan Minas Jaya layak untuk dikembangkan dengan tingkat kelayakan setiap kelas dengan skor masing-masing kelas yaitu daya tarik 846, akomodasi 144, sarana prasarana 300. Sedangkan untuk kelas aksesibilitas masih belum dapat dikatakan layak dengan skor 455 .
\end{abstract}

Kata kunci : Tahura, Kawasan Penyangga, Potensi, Kelayakan

Yan Nainggolan, Eni Suhesti, Ambar T.R/Wahana Forestra: Jurnal Kehutanan Vol 14 No 02/2019 73 


\section{PENDAHULUAN}

Hutan selain berfungsi secara ekologis juga berfungsi untuk meningkatkan perekonomian baik untuk meningkatkan pendapatan masyarakat maupun meningkatkan pemasukan bagi pemerintah daerah. Salah satu fungsi hutan yang masih belum banyak tergali adalah fungsi estetika dari hutan. Potensi ini dapat dimanfaatkan sebagai daya tarik bagi orang untuk berkunjung ketempat tersebut. Sekarang ini telah menjadi kecenderungan di masyarakat untuk kembali kegaya hidup alami (back to nature) begitu juga dengan pilihan untuk berwisata.

Dephut (1988) menyatakan bahwa semakin meningkatnya jumlah penduduk dan intensifnya pemanfaatan sumber daya alam telah menyebabkan penurunan kualitas lingkungan dan potensi sumber daya alam. Hal ini mendorong upaya untuk berusaha menetapkan kawasan konservasi yang tidak saja berfungsi sebagai penyangga proses ekologi dan pelestarian sumberdaya alam,namun juga pemanfaatan sumberdaya alam tersebut untuk kesejahteraan masyarakat secara luas dan berwawasan lingkungan. Salah satunya dengan menetapkan sebuah kawasan yang memiliki multifungsi yaitu fungsi perlindungan dan fungsi kesejahteraan bagi masyarakat diantaranya menjadikan suatu kawasan sebagai daerah tujuan wisata.

Taman Hutan Raya Sultan Syarif Hasyim merupakan kawasan konservasi yang berada di Provinsi Riau dan memiliki ekosistem hutan hujan tropika dataran rendah serta menyimpan keanekaragaman spesies flora maupun fauna. Saat ini kawasan tersebut luasannya sudah semakin berkurang karena semakin banyaknya aktifitas manusia berupa penebangan liar, perburuan satwa, maupun pengalihan fungsi lahan menjadi lahan perkebunan. Kawasan hutan di Kelurahan Minas Jaya merupakan kawasan hutan yang berstatus kawasan penyangga Taman Hutan Raya Sultan Syarif Haism, dimana lahannya mengalami kerusakan akibat bekas kebakaran lahan sehingga mengakibatkan lahan di kawasan tersebut menjadi kritis, oleh karena itu kawasan hutan tersebut harus diselamatkan dari berbagai tekanantekanan yang akan semakin merusaknya. Disamping membutuhkan waktu dan biaya yang besar untuk pengelolaannya, kawasan ini memiliki pemandangan yang cukup menarik dan bentang alam yang indah. 
Salah satu usulan bentuk pengelolaan yang menggabungkan antara pelestarian sumberdaya hutan dan kepentingan wisata adalah menjadikan kawaasan tersebut menjadi Kawasan Penyangga dengan konsep ekowisata sebagai intinya. Konsep dimana kawasan ini terbuka bagi pengunjung yang ingin menikmati berbagai pemandangan dan dapat memanfaatkannya sebagai sarana rekreasi. Dana yang diperoleh dari pengunjung dapat menjadi pemasukan dan modal dalam pengelolaan kawasan ke depannya.

Upaya pengembangan kawasan hutan di Kelurahan Minas Jaya untuk tujuan wisata masih memerlukan data-data tentang potensi dan kelayakannya dari kawasan tersebut untuk pengembangannya sebagai tujuan ekowisata. Oleh Karena itu perlu dilakukan kajian untuk memperoleh data tersebut.

Tujuan penelitian ini untuk mengetahui potensi ekowisata dan nilai kelayakan potensi ekowisata di Kawasan Penyangga Tahura Sultan Syarif Hasyim Kelurahan Minas Jaya.

\section{METODE PENELITIAN}

Tempat, Waktu, Alat dan Bahan
Penelitian ini dilakukan di Kawasan Penyangga Tahura Sultan Syarif Hasyim Kelurahan Minas Jaya. Penelitian akan dilaksanakan selama 2 bulan pada bulan April 2019 - Mei 2019. Alat yang digunakan dalam penelitian ini adalah kamera, alat tulis menulis. Bahan yang digunakan dalam penelitian ini adalah bahan pustaka terkait Kawasan Penyangga Tahura Sultan Syarif Hasyim Kelurahan Minas Jaya.

\section{Metode Pengambilan Data}

Metode pengambilan data dalam penelitian ini yaitu sebagai berikut :

1. Metode survey yaitu pengumpulan data yang dilakukan melalui metode observasi dan wawancara.Dalam wawancara digunakan kuisioner sesuai dengan pedoman ADO-ODTWA Dirjen PHKA 2003 (Matondang, 2018) .

2. Metode kepustakaan yaitu pengumpulan data dari sumbersumber berupa literatur, laporan, karya ilmiah, dan hasil penelitian yang berkaitan dengan penelititan.

3. Metode dokumentasi yaitu pengumpulan data dengan mendokumentasikan sumbersumber dilapangan yang berkaitan 
dengan permasalahan yang sedang diteliti.

4. Mengukur Kelayakan Potensi

Ekowisata

Untuk mengetahui kelayakan potensi ekowisata digunakan Pedoman Analisi Daerah Operasi Objek dan Daya

Tabel 1. Penjabaran Variabel Penelitian

\begin{tabular}{|c|c|c|c|}
\hline Variabel & $\begin{array}{c}\text { Sub } \\
\text { Variabel }\end{array}$ & Indikator & Sub Indikator \\
\hline \multirow{4}{*}{$\begin{array}{l}\text { Kelayakan Wiasata } \\
\text { Alam }\end{array}$} & \multirow{4}{*}{$\begin{array}{l}\text { Faktor kelayakan } \\
\text { ekowisata }\end{array}$} & 1. Daya Tarik & $\begin{array}{lll}\text { a. } & \text { Keunikan SDA } \\
\text { b. } & \text { Banyaknya SDA yang } \\
& \text { menonjol } \\
\text { c. } & \text { Kegiatan wisata alam yang } \\
& \text { dapat dinikmati } \\
\text { d. } & \text { Kebersihan lokasi objek } \\
& \text { wisata } \\
\text { e. } & \text { Keamanan kawasan } \\
\text { f. } & \text { Kenyamanan }\end{array}$ \\
\hline & & 2. Aksesibilitas & \begin{tabular}{|ll} 
a. & Kondisi jalan \\
b. & Jarak dari kota \\
c. & Tipe jalan \\
d. & Waktu tempuh \\
\end{tabular} \\
\hline & & 3. $\quad$ Akomodasi & \begin{tabular}{|ll} 
a. & Jumlah akomodasi \\
b. & Jumlah kamar
\end{tabular} \\
\hline & & 4. $\begin{array}{l}\text { Sarana dan prasarana } \\
\text { penunjang }\end{array}$ & $\begin{array}{ll}\text { a. Prasarana penunjang } \\
\text { b. Sarana penunjang }\end{array}$ \\
\hline
\end{tabular}

Sumber : Kriteria Penilaian Objek dan Daya Tarik Wisata Menurut Pedoman Analisis Daerah Operasi Objek dan Daya Tarik Wisata Alam (ADOODTWA) Dirjen PHKA tahun 2003 (Matondang, 2018)

\section{Analisis Data}

Analisis data dilakukan dengan menggunakan dua metode yaitu :

1. Analisis kualitatif deskriptif yaitu metode analisis yang bertujuan untuk menggambarkan dan menjelaskan pada potensi objek ekowisata dalam kawasan
Tarik Wisata Alam ADO-ODTWA Dirjen PHKA 2003. Adapun komponen yang akan dicatat dan dinilai adalah daya tarik, aksesibilitas, akomodasi, sarana dan prasarana penunjang. Adapun penjabaran mengenai variabel penelitian ini dapat dilihat pada Tabel 1. 
Jumlah nilai untuk satu kriteria penilaian ODTWA dapat dihitung dengan rumus :

$\mathrm{S}=\mathrm{N} \times \mathrm{B}$

Keterangan :

$\mathrm{S}=$ skor/nilai suatu kriteria

$\mathrm{N}=$ jumlah nilai unsur-unsur pada kriteria

$\mathrm{B}=$ bobot nilai

(Ginting, Patana, \& Rahmawaty, 2015)

Skor yang diperoleh kemudian dibandingkan dengan skor total suatu kriteria. Skor yang diperoleh dari setiap 77ariable akan ditentukan tingkat kelayakanya menggunakan rumus interval yaitu :

Interval $=\frac{\text { Skor maksimum }- \text { Skor minimum }}{3}$

Sumber : Pedoman ADO-ODTWA Dirjen PHKA 2003 (Matondang, 2018)

Untuk menentukan layak atau tidak layaknya suatu lokasi dijadikan sebagai tujuan wisata maka digunakan hasil perhitungan penilaian daya tarik wisata seperti pada Tabel

Tabel 2. Hasil Penilaian Objek dan Daya Tarik Wisata

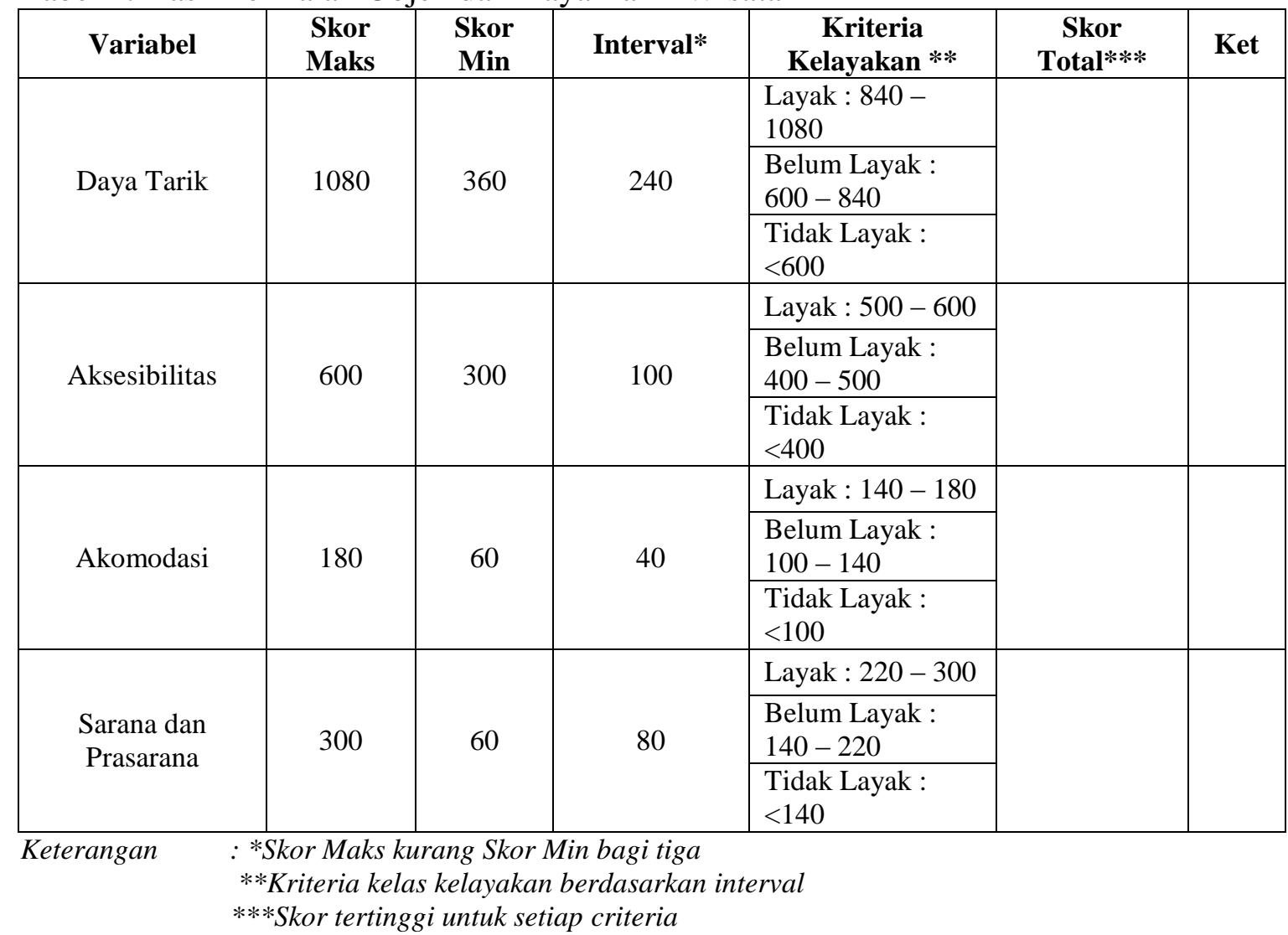




\section{HASIL DAN PEMBAHASAN}

Potensi Ekowisata di Kawasan

Penyangga Tahura Sultan Syarif Hasyim

Kelurahan Minas Jaya

Potensi yang terdapat dalam

Kawasan Penyangga Tahura Sultan Syarif

Hasyim Kelurahan Minas Jaya yaitu potensi flora dan fauna, serta potensi panorama bentang alamnya.

\section{Potensi Panorama Alam}

Keindahan panorama alam di Kawasan Penyangga Tahura Sultan Syarif Hasyim Kelurahan Minas Jaya. Hutan yang diisi dengan vegetasi-vegetasi yang beranekaragam jenisnya, menambah daya tarik panorama alam dengan keunikan bentuk dan tampilan vegetasi-vegetasi tersebut. Kawasan hutan dengan lahan yang membentuk seperti pulau-pulau kecil yang mengelilingi danau juga menambah keunikan panorama alam dikawasan ini..

Untuk mencapai kawasan ini dapat ditempuh dengan kendaraan bermotor dan mobil dengan jarak $\pm 5 \mathrm{~km}$ dan waktu tempuh sekitar 20 menit dari pusat kota.

\section{Potensi Danau}

Danau di Kawasan Penyangga Tahura Sultan Syarif Hasyim Kelurahan Minas Jaya ini merupakan sumber mata air utama bagi masyarakat sekitar untuk menyirami tanaman perkebunan mereka, sehingga masyarakat turut menjaga kondisi danau agar tidak tercemar, sehingga kondisi lingkungan danau bersih dan jauh dari pencemaran.

\section{Potensi Flora dan Fauna}

Hasil pengamatan langsung dengan membuat jalur tracking, ditemui beberapa jenis flora dan fauna yang terdapat dalam Kawasan Penyangga Tahura Sultan Syarif Hasyim Kelurahan Minas Jaya. Jenis flora yang ditemui sepanjang jalur tracking yaitu antara lain Cokelat (Theobroma caco), Jeruk kasturi (Citrofortunella mitis), jenis mangga (Mangifera sp), jenis Terap (Artocarpus $s p$ ), jenis Terentang (Campnosperma $s p$ ), jenis Kantung Semar (Nepenthes sp), jenis Mahang (Macaranga $s p$ ), jenis Beringin (Ficus $s p$ ), Sendoksendok (Endospermum $s p$ ), jenis Jambujambuan (Syzygium sp).

Sedangan jenis fauna yang terlihat disepanjang jalur tracking yaitu beberapa 
jenis Kupu-kupu (Delias $s p$ ), jenis Capung (Aesha sp), jenis burung salah seperti Raja Udang (Alcedo meninting), Perkutut (Geopelia striata), Balam (Spilopelia sp), Betet (Psittacula alexandri), Murai Daun (Chloropsis sonnerati), Monyet (Macaca $s p$ ), Siamang (Symphalangus sp), Babi Hutan (Sus sp).

\section{Penilaian Objek dan Daya Tarik Wisata}

Komponen yang dinilai dari

Kawasan Penyangga Tahura Sultan Syarif

Hasyim Kelurahan Minas Jaya adalah daya tarik lokasi kawasan tersebut, aksesibilitas untuk bisa mencapai lokasi kawasan, akomodasi yang ada disekitar kawasan dan juga sarana dan prasarana penunjang yang mendukung perkembangan lokasi.

\section{Daya Tarik}

Daya tarik suatu kawasan merupakan hal utama yang menjadikan kawasan tersebut menarik minat wisatawan untuk berkunjung dan melakukan kegiatan wisata. Hasil penilaian. diperoleh nilai terhadap komponen daya tarik dapat dilihat pada Tabel 3 .

Tabel 3. Hasil Penilaian Terhadap Komponen Daya Tarik di Kawasan Penyangga

Tahura Sultan Syarif Hasyim Kelurahan Minas Jaya

\begin{tabular}{|l|l|l|l|l|}
\hline No & Unsur/Sub Unsur & Bobot & Nilai & Skor Total* \\
\hline 1 & Keunikan SDA & 6 & 20 & 120 \\
\hline 2 & Banyaknya SDA yang menonjol dapat & 6 & 20 & 120 \\
\hline 3 & $\begin{array}{l}\text { Kegiatan wisata alam yang dapan } \\
\text { dilakukan }\end{array}$ & 6 & 30 & 180 \\
\hline 4 & Kebersihan lokasi & 6 & 18 & 108 \\
\hline 5 & Keamanan kawasan & 6 & 25 & 150 \\
\hline 6 & Kenyamanan & & 28 & 168 \\
\hline & Skor Total & $\mathbf{1 4 1}$ & $\mathbf{8 4 6}$ \\
\hline
\end{tabular}

Keterangan $=*$ Hasil kali antara bobot dengan nilai

Sumber : Data Primer 2019

Hasil penilaian dari Tabel 3. dapat dilihat bahwa skor total yang diperoleh adalah 846, skor ini diperoleh dari hasil kali antara bobot dengan nilai dari setiap sub unsur dan kemudian ditotalkan seluruhnya, dimana pada kriteria keunikan sumber daya alam memperoleh nilai 20 , kriteria banyaknya sumber daya alam yang 
menonjol diperoleh nilai 20, penilaian kegiatan wisata yang dapat dilakukan diperoleh nilai 30, penilaian kebersihan lokasi memperoleh nilai 18, kemudian pada penilaian keamanan kawasan nilai yang didapatkan adalah 25 dan penilaian kenyamanan kawasan diperoleh nilai 28.

\section{Aksesibilitas}

Kurangnya perhatian pemerintah terhadap infrastruktur di Kawasan Penyangga Tahura Sultan Syarif Hasyim Kelurahan Minas Jaya ini, membuat kawasan ini sedikit sulit untuk dikunjungi. Tipe jalan menuju Kawasan Penyangga Tahura Sultan Syarif Hasyim Kelurahan Minas Jaya ini masih bertipe tanah, masih banyak lubang-lubang besar dijalan. Penilaian terhadap aksesibilitas menuju Kawasan Penyangga Tahura Sultan Syarif Hasyim Kelurahan Minas Jaya dapat dilihat pada tabel 4 .
Tabel 4. Hasil Penilaian Terhadap Komponen Aksesibilitas Menuju Kawasan Penyangga Tahura Sultan Syarif Hasyim Kelurahan Minas Jaya

\begin{tabular}{|l|l|l|l|l|}
\hline No & $\begin{array}{l}\text { Unsur/Su } \\
\text { b Unsur }\end{array}$ & $\begin{array}{l}\text { Bobo } \\
\text { t }\end{array}$ & $\begin{array}{l}\text { Nila } \\
\text { i }\end{array}$ & $\begin{array}{l}\text { Skor } \\
\text { Total } \\
\text { " }\end{array}$ \\
\hline 1 & $\begin{array}{l}\text { Kondisi } \\
\text { Jalan }\end{array}$ & 5 & 16 & 80 \\
\hline 2 & Jarak & 5 & 30 & 150 \\
\hline 3 & Tipe Jalan & 5 & 15 & 75 \\
\hline 4 & $\begin{array}{l}\text { Waktu } \\
\text { tempuh } \\
\text { dari pusat } \\
\text { kota }\end{array}$ & 5 & 30 & 150 \\
\hline & Skor Total & & $\mathbf{9 1}$ & $\mathbf{4 5 5}$ \\
\hline
\end{tabular}

Keterangan $={ }^{*}$ Hasil kali antara bobot dengan nilai

Sumber : Data Primer 2019

Hasil penilaian aksesibilitas pada tabel 4 , menunjukan bahwa skor total yang diperoleh adalah 455. Nilai ini diperoleh dari penilaian setiap sub unsur dimana pada penilaian kondisi jalan menuju Kawasan Penyangga Tahura Sultan Syarif Hasyim Kelurahan Minas Jaya diperoleh adalah 16, dengan tipe jalan tanah sehingga diperoleh nilai 15 namun dengan lokasi yang jaraknya lumayan dekat sehingga nilai yang diperoleh 30, serta dari pusat kota menuju Kawasan Penyangga Tahura Sultan Syarif Hasyim Kelurahan Minas Jaya hanya memerlukan waktu \pm 20 menit sehingga nilai yang diperoleh adalah 30 . 


\section{Akomodasi}

Kawasan Penyangga Tahura Sultan Syarif Hasyim Kelurahan Minas Jaya tidak menyediakan akomodasi di dalam kawasan tersebut. Penilaian untuk akomodasi di sekitar Kawasan Penyangga Tahura Sultan Syarif Hasyim Kelurahan Minas Jaya dapat dilihat pada Tabel 5.

Tabel 5. Hasil Penilaian Akomodasi Sekitar Kawasan Penyangga Tahura Sultan Syarif Hasyim Kelurahan Minas Jaya (Radius $15 \mathrm{KM}$ dari Objek)

\begin{tabular}{|l|l|l|l|l|}
\hline No & $\begin{array}{l}\text { Unsur/Sub } \\
\text { Unsur }\end{array}$ & Bobot & Nilai & $\begin{array}{c}\text { Skor } \\
\text { Total" }\end{array}$ \\
\hline 1 & $\begin{array}{l}\text { Jumlah } \\
\text { Akomodasi }\end{array}$ & 3 & 27 & 81 \\
\hline 2 & $\begin{array}{l}\text { Jumlah } \\
\text { Kamar }\end{array}$ & 3 & 21 & 63 \\
\hline & Skor Total & & 48 & 144 \\
\hline
\end{tabular}

Keterangan $=*$ Hasil kali antara bobot dengan nilai

Sumber : Data Primer 2019

Pada tabel 5. dapat dilihat bahwa skor total yang diperoleh adalah 144, nilai ini didapat dari penilaian akomodasi yang berada di sekitar kawasan dengan radius 15 $\mathrm{km}$ dari objek, dari penilaian tersebut maka didapatkan sejumlah penginapan sekitar lebih dari tiga penginapan sehingga nilai yang didapatkan 27, dengan jumlah kamar rata-rata tiga puluh sampai tujuh puluh kamar sehingga nilai yang didapatkan 21 .

\section{Sarana dan Prasarana Penunjang}

Didalam Kawasan Penyangga

Tahura Sultan Syarif Hasyim Kelurahan Minas Jaya terdapat prasarana seperti jaringan listrik, jaringan air minum, dan jaringan telepon. Namun prasarana seperti kantor pos dan puskesmas tidak terdapat didalam lokasi, namun dapat dijumpai disekitar kawasan dalam radius $10 \mathrm{~km}$ dari lokasi. Penilaian terhadap sarana dan prasarana penunjang dalam Kawasan Penyangga Tahura Sultan Syarif Hasyim Kelurahan Minas Jaya dapat dilihat pada tabel 6.

Tabel 6. Hasil Penilaian Terhadap Sarana dan Prasarana Penunjang (Radius $10 \mathrm{KM}$ dari Objek)

\begin{tabular}{|l|l|l|l|l|}
\hline $\begin{array}{l}\text { N } \\
\text { o }\end{array}$ & $\begin{array}{l}\text { Unsur/Sub } \\
\text { Unsur }\end{array}$ & $\begin{array}{l}\text { Bobo } \\
\text { t }\end{array}$ & $\begin{array}{l}\text { Nila } \\
\text { i }\end{array}$ & $\begin{array}{l}\text { Skor } \\
\text { Total } \\
\text { " }\end{array}$ \\
\hline 1 & Prasarana & 3 & 50 & 150 \\
\hline 2 & $\begin{array}{l}\text { Sarana } \\
\text { Penunjang }\end{array}$ & 3 & 50 & 150 \\
\hline & Skor Total & & 100 & 300 \\
\hline
\end{tabular}

Keterangan $=*$ Hasil kali antara bobot dengan nilai

Sumber : Data Primer 2019

Hasil penilaian pada tabel 6 . diperoleh skor total yaitu 300, hasil ini diperoleh dari penilaian sarana dan prasarana penunjang nilai yang didapatkan yaitu 50. Sedangkan untuk sarana penunjang mendapatkan nilai 50. 
Analisis Kelayakan Objek dan Daya

Tarik Ekowisata Kawasan Penyangga

Tahura Sultan Syarif Hasyim

Kelurahan Minas Jaya

Penelitian yang dilakukan dengan observasi langsung dalam Kawasan Penyangga Tahura Sultan Syarif Hasyim Kelurahan Minas Jaya untuk mengetahui potensinya, dengan penilaian beberapa komponen atau kriteria yaitu daya tarik, aksesibilitas, akomodasi serta sarana dan prasarana penunjang yang mendukung perkembangan lokasi wisata

$$
\text { Hasil penilaian terhadap }
$$
komponen-komponen di Kawasan Penyangga Tahura Sultan Syarif Hasyim Kelurahan Minas Jaya dapat dilihat pada tabel 7 .

Tabel 7. Hasil Penilaian Objek Dan Daya Tarik Wisata Kawasan Penyangga Tahura Sultan Syarif Hasyim Kelurahan Minas Jaya

\begin{tabular}{|c|c|c|c|c|c|c|}
\hline Variabel & $\begin{array}{l}\text { Skor } \\
\text { Maks }\end{array}$ & $\begin{array}{l}\text { Skor } \\
\text { Min }\end{array}$ & Interval & Kriteria Kelayakan & $\begin{array}{l}\text { Skor } \\
\text { Total }\end{array}$ & Ket \\
\hline \multirow{3}{*}{ Daya Tarik } & \multirow{3}{*}{1080} & \multirow{3}{*}{360} & \multirow{3}{*}{240} & Layak : 840-1080 & \multirow{3}{*}{846} & \multirow{3}{*}{ Layak } \\
\hline & & & & Belum Layak : 600-840 & & \\
\hline & & & & Tidak Layak : <600 & & \\
\hline \multirow{3}{*}{ Aksesibilitas } & \multirow{3}{*}{600} & \multirow{3}{*}{300} & \multirow{3}{*}{100} & Layak : 500-600 & \multirow{3}{*}{455} & \multirow{3}{*}{$\begin{array}{l}\text { Belun } \\
\text { Layak }\end{array}$} \\
\hline & & & & Belum Layak : 400-500 & & \\
\hline & & & & Tidak Layak : $<400$ & & \\
\hline \multirow{3}{*}{ Akomodasi } & \multirow{3}{*}{180} & \multirow{3}{*}{60} & \multirow{3}{*}{40} & Layak : $140-180$ & \multirow{3}{*}{144} & \multirow{3}{*}{ Layak } \\
\hline & & & & Belum Layak : 100-140 & & \\
\hline & & & & Tidak Layak : $<100$ & & \\
\hline \multirow{3}{*}{$\begin{array}{l}\text { Sarana } \\
\text { Prasarana }\end{array}$} & \multirow{3}{*}{300} & \multirow{3}{*}{60} & \multirow{3}{*}{80} & Layak : 220-300 & \multirow{3}{*}{300} & \multirow{3}{*}{ Layak } \\
\hline & & & & Belum Layak : 140-220 & & \\
\hline & & & & Tidak Layak : $<140$ & & \\
\hline
\end{tabular}

Sumber : Data Primer 2019

Hasil perhitungan tabel 7. dan dijadikan daerah tujuan wisata. Hal ini menunjukan bahwa Kawasan Penyangga disimpulkan sesuai dengan tingkat kriteria Tahura Sultan Syarif Hasyim Kelurahan Minas Jaya berpotensi untuk dikembangkan kelayakan yang ditentukan pada setiap kelasnya menyatakan bahwa setiap kelas 
dinyatakan layak dengan nilai masingmasing kriteria yaitu, daya tarik dengan nilai 846 , akomodasi 144 , serta sarana dan prasarana dengan nilai 300. Namun terdapat satu aspek yang menyatakan bahwa masih belum layak untuk dikembangkan sebagai daerah tujuan wisata, yaitu pada aspek aksesibilitas dimana masih mendapatkan nilai 455 yang berarti masih belum layak.

\section{KESIMPULAN DAN SARAN}

\section{A. Kesimpulan}

Berdasarkan hasil penelitian yang diperoleh maka dapat ditarik kesimpulan yaitu: Kawasan Penyangga Tahura Sultan Syarif Hasyim Kelurahan Minas Jaya menyimpan potensi objek ekowisata berupa keindahan panorama alam, serta keragaman jenis flora dan fauna. Berdasarkan hasil penilaian kelayakan potensi ekowisata pada Kawasan Penyangga Tahura Sultan Syarif Hasyim Kelurahan Minas Jaya dapat diketahui bahwa kawasan tersebut layak untuk dikembangkan dengan tingkat kelayakan yang dinyatakan berdasarkan kriteria kelayakan setiap kelas yang menunjukan bahwa setiap kelas dinyatakan layak dengan skor masing-masing kelas yaitu daya tarik 846, akomodasi 144, sarana prasarana 300. Sedangkan untuk kelas aksesibilitas masih belum dapat dikatakan layak karena dalam penilaian kelayakan potensi ekowisata kelas aksesibilitas mashi mendapatkan skor 455 .

\section{B. Saran}

Berdasarkan hasil penelitian di Kawasan Penyangga Tahura Sultan Syarif Hasyim Kelurahan Minas Jaya maka disarankan bahwa perlunya pengadaan fasilitas berupa infrastruktur dalam Kawasan Penyangga Tahura Sultan Syarif Hasyim Kelurahan Minas Jaya untuk menunjang kawasan tersebut.

Pemerintah serta masyarakat harus lebih memperhatikan kawasan tersebut agar kelestarian kawasan tetap terjaga. Pengembangan Kawasan Penyangga Tahura Sultan Syarif Hasyim Kelurahan Minas Jaya sangat perlu dilakukan karena kawasan tersebut berpotensi untuk mendatangkan rupiah dan berpotensi untuk terbukanya lapangan kerja bagi masyarakat setempat. Pejelasan pengelola dan pengelolaan kawasan yang baik sangat perlu umtuk menunjang kawasan tersebut. Dilakukan penelitian pengembangan yang berkaitan dengan penelitian ini. 


\section{DAFTAR PUSTAKA}

Dephut. (1988). Pembangunan Taman Hutan Raya. Bogor: Departemen Kehutanan.

Ginting, I. A., Patana, P., \& Rahmawaty. (2015). Penilaian dan Pengembangan Potensi Objek dan Daya Tarik Wisata Alam di Taman Wisata Alam ( TWA ) Sibolangit. Peronema Forestry Science Journal, Vol. 2, pp. 74-81. Medan: Universitas Sumatra Utara.

Matondang, D. N. H. (2018). Daya Tarik Wisata Alam Buluh Cina Kecamatan Siak Hulu Kabupaten Kampar Riau. Universitas Lancang Kuning. 